\title{
Association of RET codon 691 polymorphism in radiation-induced human thyroid tumours with C-cell hyperplasia in peritumoural tissue
}

\author{
A Bounacer*,1,4, JA Du Villard', R Wicker', B Caillou², M Schlumberger³, A Sarasin' and HG Suárez' \\ 'Laboratoire d'Instabilité Génétique et Cancer (UPR 2169), Institut de Recherches sur le Cancer, C.N.R.S. - IFR 89, B.P. n 8, 94801 Villejuif Cedex, France; \\ ${ }^{2}$ Service de Pathologie A Institut Gustave-Roussy, 94805 Villejuif Cedex, France; ${ }^{3}$ Service de Médecine Nucléaire, Institut Gustave-Roussy, 94805 Villejuif \\ Cedex, France
}

The RET proto-oncogene encodes a protein structurally related to transmembrane receptors with an intracellular tyrosine kinase domain. In human thyroid gland, the RET proto-oncogene is normally expressed in parafollicular C-cells. Thyroid C-cell hyperplasia is associated with inherited medullary thyroid carcinomas and is considered as a pre-neoplastic stage of C-cells disease. It has also been observed in thyroid tissues adjacent to follicular and papillary carcinomas. In order to study the relationship between a misfunctioning of the RET proto-oncogene and the presence of C-cell hyperplasia, we compared a series of thyroid glands presenting sporadic or radiation-associated tumours, as well as samples of unrelated normal thyroid tissues, for alteration in exons 10 and II of the gene and for the presence or absence of C-cell hyperplasia. Here we report a significantly higher frequency of C-cell hyperplasia present in peritumoural thyroid tissues of radiation-induced epithelial thyroid tumours, than in peritumoural of sporadic thyroid tumours or in control normal thyroid tissues $(P=0.001)$. A G69IS RET polymorphism was present with a higher frequency in radiation-induced epithelial thyroid tumours (55\%) than in sporadic tumours (20\%) and in control normal thyroid tissues (15\%). Interestingly, this polymorphism was associated in the majority (88\%) of radiation-induced tumours with a C-cell hyperplasia in the peritumoural tissues. Several explanations for this association are discussed.

British Journal of Cancer (2002) 86, 1929 - 1936. doi:I0.1038/sj.bjc.660037I www.bjcancer.com

(C) 2002 Cancer Research UK

Keywords: C-cell hyperplasia; thyroid tumours; radiation; polymorphism; RET; RETIPTC

Since 1950, when the first epidemiological study relating external beam radiation exposure and thyroid cancer was published (Duffy and Fitzgerald, 1950), an increased incidence of this type of tumour has been observed in populations including atomic bomb survivors (Thompson et al, 1994), inhabitants of regions affected by a thermonuclear test (Conard, 1984) and patients with a history of external radiation for benign or malignant conditions (Shore, 1992). Radiation-associated thyroid tumours were also observed in children contaminated in Ukraine and Belarus as a consequence of the Chernobyl accident (Kazakov et al, 1992).

Radiation-associated thyroid tumours are the most frequent radiation-induced tumours in man and the increase in the relative risk of developing a thyroid tumour following a radiation dose of $1 \mathrm{~Gy}$ to the gland during childhood, is equal to 7.7 (Ron et al, 1995). Studies concerning the research of genetic alterations in radiation-induced epithelial thyroid tumours, have concerned the RAS, GSP, RET, TRK, and P53 genes (for review Suarez, 1998). These data showed a crucial role for RET activating rearrangements in the initiation and/or the development of the radiation-associated epithelial thyroid tumourigenic process (Suarez, 1998).

\footnotetext{
*Correspondence: A Bounacer; E-mail: BounacerA@cf.ac.uk

${ }^{4}$ Current address; Department of Pathology, University of Wales College of Medicine, Heath Park, Cardiff CFI4 4XN, UK;
}

Received 10 January 2002; revised 15 April 2002; accepted 22 April 2002
The RET proto-oncogene located on chromosome 10q11.2 encodes a protein structurally related to transmembrane receptors with an intracellular tyrosine kinase domain (Takahashi et al, 1985; Takahashi and Cooper, 1987). The ligands for RET have been recently identified as neurotrophic factors of the glial-cell-line derived neurotrophic factor (GDNF) family, including GDNF, neurturin, artemin, and perseptin (reviewed in Airaksinen et al, 1999; Baloh et al, 2000). The gene is expressed in a variety of neuronal cell lineages as well as in the kidney and enteric nervous system (Pachnis et al, 1993). In the normal human thyroid gland, the RET proto-oncogene is normally expressed in parafollicular Ccells, suggesting its involvement in the growth regulation of these cells (Fabien et al, 1994). The identification of germline point mutations in different domains of the RET proto-oncogene in inherited human diseases, namely Multiple Endocrine Neoplasia type 2A and 2B (MEN2A and MEN2B), familial or sporadic medullary thyroid carcinoma (MTC) and Hirschsprung's disease (Donis-Keller et al, 1993; Mulligan et al, 1993; Edery et al, 1994; Hofstra et al, 1994; for review Eng, 1999), confirms that this gene plays a critical role in the differentiation and growth of specific cell lineages of neural crest origin (i.e. thyroid C-cells).

Thyroid C-cell hyperplasia $(\mathrm{CCH})$ was first described in the early 1970's as a lesion associated with familial MTC and MEN 2A and 2B (Wolfe et al, 1973; DeLellis and Wolfe, 1981; LiVolsi, 1997), and is considered as a pre-neoplastic stage of C-cell disease. $\mathrm{CCH}$ was also found to be associated with several other conditions. 
In fact, $\mathrm{CCH}$ was recognised in some patients with Hashimoto thyroiditis (Libbey et al, 1989) as well as in some other patients with chronic lymphocytic thyroiditis not within the context of MTC or MEN (Guyetant et al, 1994). In addition, CCH was also observed for the first time by Albores-Saavedra et al (1988), in thyroid tissue adjacent to follicular and papillary neoplasms.

In order to look for an eventual relationship between the presence of C-cell hyperplasia in normal thyroid tissues surrounding epithelial thyroid tumours and a possible misfunctioning of the RET proto-oncogene, we analysed a series of thyroid glands presenting sporadic or radiation-associated tumours as well as samples of unrelated normal thyroid tissue.

\section{MATERIALS AND METHODS}

Tumoural thyroid tissues were collected at the Gustave Roussy Institute (Villejuif, France) and were histologically classified according to the WHO classification (Hedinger et al, 1988). Normal unrelated thyroid tissues were collected at the Hospital de Clinicas of Buenos Aires (Argentina) by Dr J Garcia. A total of 29 thyroid tumours obtained from patients with a history of external irradiation for benign or malignant conditions were examined: 14 follicular adenomas, 11 papillary carcinomas (PTC) and 4 widely invasive follicular carcinomas (WIFC) (Table 1). As controls we studied 29 human thyroid tumours collected from patients without any history of radiation (15 follicular adenomas, 12 PTC and 2 WIFC) (Table 2) and 20 samples of unrelated normal thyroid tissue.
The presence of a $\mathrm{C}$-cell hyperplasia $(\mathrm{CCH})$ was investigated in paraffin embedded tissue sections, using an immunohistochemical technique previously described (Guyetant et al, 1999). The calcitonin polyclonal antibody used was from DAKO (A576). The test was performed with a streptavidin-Biotin-Peroxydase kit (LSAB-Dako-K675), after treatment with diaminobenzidine. The nuclei were stained with Mayer's Haematoxylin. The slides showing a $\mathrm{CCH}$ in thyroid tissue adjacent to follicular cell radio-induced tumours were carefully examined. One example of $\mathrm{CCH}$ in peritumoural tissue of a patient with a radiation-induced thyroid tumour is shown in Figure 1. A C-cell hyperplasia diagnosis was made when at least three low-power fields $(\times 100$ magnification $)$ containing more than 50 calcitonin-immunostained C-cells were observed (Guyetant et al, 1994).

Genomic DNA was extracted from frozen and/or paraffin embedded thyroid tissue samples, as described by Suarez et al (1990, 1991). Amplification of exons 10 and 11 of RET gene, was carried out with $250 \mathrm{ng}$ genomic DNA, $250 \mathrm{nmol}$ of each primer, $200 \mathrm{nmol}$ dNTPs, Taq polymerase buffer (Perkin Elmer), $1.5 \mathrm{mmol} \mathrm{MgCl}_{2}$ and $2 \mathrm{U}$ Taq DNA polymerase (Perkin Elmer Cetus). The following temperature cycling conditions were used: one cycle $3 \mathrm{~min}$ at $94^{\circ} \mathrm{C}$ and $2 \mathrm{~min}$ at $68^{\circ} \mathrm{C}$ (exon 10) or $60^{\circ} \mathrm{C}$ (exon 11), followed by 35 cycles of $30 \mathrm{~s}$ at $94^{\circ} \mathrm{C}, 30 \mathrm{~s}$ at $68^{\circ} \mathrm{C}$ (exon 10) or $60^{\circ} \mathrm{C}$ (exon 11) and $1 \mathrm{~min}$ at $72^{\circ} \mathrm{C}$. At the end of the 35 cycles, the PCR products were extended for $10 \mathrm{~min}$ at $72^{\circ} \mathrm{C}$. Two pairs of primers were used to amplify exons 10 and 11 of the RET gene. These primers were: exon 10: (sense) $5^{\prime}$-gcgccccaggaggctgagtg- $3^{\prime}$ and (anti-sense) $5^{\prime}$-cgtggtggtccoggccgcc- $3^{\prime}$; exon11: (sense)

Table I Association of RET codon 69l (GGT $\rightarrow$ AGT: gly $\rightarrow$ ser) polymorphism in radiation-induced thyroid tumours with C-cell hyperplasia in peritumoural tissue

\begin{tabular}{|c|c|c|c|c|c|c|}
\hline \multirow[b]{2}{*}{ Sample } & \multirow{2}{*}{$\begin{array}{c}\text { Age at } \\
\text { irradiation (year) } \\
\text { and dose (Gy) }\end{array}$} & \multirow{2}{*}{$\begin{array}{c}\text { Sex and Age at } \\
\text { tumour diagnosis } \\
\text { (year) }\end{array}$} & \multirow[b]{2}{*}{ Histology ${ }^{b}$} & \multirow{2}{*}{$\begin{array}{l}\text { Presence of C-cell } \\
\text { hyperplasia in } \\
\text { peritumoural tissue }\end{array}$} & \multicolumn{2}{|c|}{ Banl digestion products } \\
\hline & & & & & Tumour & Lymphocyte \\
\hline $\mathrm{Ti}^{\mathrm{C}} 5^{\mathrm{C}}$ & $2 / 0.1$ & $F / 5$ & PTC & + & $\mathrm{Al} / \mathrm{A} 2^{\mathrm{d}}$ & \\
\hline Tilol & $36 / 10$ & $F / 47$ & PTC & - & Al & Al \\
\hline Ti228 & $5 / 7.3$ & $F / 25$ & PTC & - & Al & \\
\hline Ti230 & $3 / n d$ & $F / 38$ & PTC & + & A2 & $\mathrm{Al} / \mathrm{A} 2$ \\
\hline Ti231 & |/4.5 & $F / 20$ & PTC & - & Al & \\
\hline Ti236 & $24 / 14$ & $M / 34$ & PTC & - & Al & Al \\
\hline Ti247 ${ }^{\mathrm{c}}$ & 5/nd & $F / 24$ & PTC & + & $\mathrm{A} 2$ & $\mathrm{~A} 1 / \mathrm{A} 2$ \\
\hline Ti $248^{c}$ & $2 / n d$ & $F / 22$ & PTC & + & $\mathrm{Al} / \mathrm{A} 2$ & \\
\hline Ti249c & |/0.24 & $M / 23$ & PTC & + & $\mathrm{A} 2$ & $\mathrm{Al} / \mathrm{A} 2$ \\
\hline Ti250 & 9/9 & $M / 28$ & PTC & - & Al & \\
\hline $\mathrm{Ti} 25 \mathrm{l}^{\mathrm{c}}$ & $13 /$ nd & $F / 28$ & PTC & - & $\mathrm{A} \mid / \mathrm{A} 2$ & \\
\hline $\mathrm{Ti} 3 l^{\mathrm{c}}$ & $12 / \mathrm{nd}$ & $\mathrm{F} / 42$ & Macr. Ad. & + & $\mathrm{A} 2$ & \\
\hline Ti216 & $44 / n d$ & $F / 58$ & Macr. Ad. & - & Al & \\
\hline Ti238 & $25 / n d$ & $M / 53$ & Macr. Ad. & - & Al & Al \\
\hline Ti27I & $6 / 14$ & $M / 21$ & Macr. Ad. & + & Al & \\
\hline Ti225 & $12 / 10.5$ & $F / 38$ & Mix. Ad. & - & Al & $\mathrm{Al}$ \\
\hline Ti234 & $4 / 15.5$ & $\mathrm{~F} / \mathrm{l} 8$ & Mix. Ad. & + & $\mathrm{A} 2$ & $\mathrm{Al} / \mathrm{A} 2$ \\
\hline Ті274 & $1 / 0.18$ & $F / 27$ & Mix. Ad. & + & Al & \\
\hline Til2I & $26 / 12$ & $F / 46$ & Micr. Ad. & - & Al & Al \\
\hline Til54 & | $/ 0.2$ & $F / 33$ & Micr. Ad. & + & $A 2$ & \\
\hline Ti226 ${ }^{c}$ & $13 / 13$ & $M / 34$ & Micr. Ad. & + & $\mathrm{A} 2$ & $\mathrm{Al} / \mathrm{A} 2$ \\
\hline $\mathrm{Ti} 232^{\mathrm{c}}$ & $4 / 29.2$ & $M / 21$ & Micr. Ad. & + & $\mathrm{A} 2$ & \\
\hline Ti239 & $2 / n d$ & $F / 22$ & Micr. Ad. & + & $\mathrm{A} 2$ & Al/A2 \\
\hline Ti252 ${ }^{c}$ & $1 / 10$ & $M / 27$ & Micr. Ad. & - & $\mathrm{Al} / \mathrm{A} 2$ & \\
\hline Ti270 & $3 / 13$ & $M / 20$ & Micr. Ad. & + & $\mathrm{A} 2$ & \\
\hline Ti88 & $8 / \mathrm{nd}$ & $F / 45$ & WIFC & - & Al & \\
\hline Til55 & $23 / n d$ & $M / 33$ & WIFC & - & Al & \\
\hline Ti233 & I/nd & $F / 6$ & WIFC & + & $\mathrm{A} 2$ & $\mathrm{~A} 2$ \\
\hline Ti255 & 14/nd & $M / 27$ & WIFC & + & A2 & \\
\hline
\end{tabular}

${ }^{a}$ Dose received by the thyroid gland calculated according to Diallo et al (1996); ${ }^{b}$ Macr. Ad.=macrofollicular adenoma; Mix. Ad.=mixed adenoma (macro and microfollicular regions); Micr. Ad.=microfollicular adenoma; PTC=papillary thyroid carcinoma; WIFC=widely invasive follicular carcinoma. 'Tumours positive for RETIPTCI or RETIPTC3 (Bounacer et al, 1997). 'AI is always defined as the wild type allele with the restriction site present, $A 2$ with the restriction site absent. 
Table 2 RET polymorphism in codon 69। (GGT $\rightarrow$ AGT: gly $\rightarrow$ ser) and C-cell hyperplasia in thyroid glands with sporadic tumours

\begin{tabular}{|c|c|c|c|c|}
\hline Sample & $\begin{array}{c}\text { Sex and age } \\
\text { at tumour diagnosis } \\
\text { (year) }\end{array}$ & Histology ${ }^{a}$ & $\begin{array}{l}\text { Presence of C-cell } \\
\text { hyperplasia in } \\
\text { peritumoural tissue }\end{array}$ & Banl digestion products ${ }^{c}$ \\
\hline Ti8 & $F / 37$ & PTC & - & Al \\
\hline Til 8 & $F / I 5$ & PTC & - & Al \\
\hline Til9 & $M / 22$ & PTC & - & Al \\
\hline Ti24 & $\mathrm{F} / 30$ & PTC & - & Al \\
\hline Ti33 & $M / 39$ & PTC & - & $\mathrm{Al} / \mathrm{A} 2$ \\
\hline Ti38 & $M / 56$ & PTC & - & $\mathrm{Al} / \mathrm{A} 2$ \\
\hline Ti40 b & $F / 32$ & PTC & + & $\mathrm{A} 2$ \\
\hline Ti43 & $F / 46$ & PTC & - & Al \\
\hline Ti48 & $F / 39$ & PTC & - & Al \\
\hline Til02 & $M / 55$ & PTC & - & Al \\
\hline Til22 & $M / 36$ & PTC & - & Al \\
\hline Til25 & $F / 63$ & PTC & - & Al \\
\hline Til6 & $F / 26$ & Mac. Ad. & - & Al/A2 \\
\hline Ti27 & $F / 22$ & Mac. Ad. & - & Al \\
\hline Ti37 & $F / 29$ & Mac. Ad. & - & Al \\
\hline Ti56 & $F / 35$ & Mac. Ad. & + & Al \\
\hline Ti66 & $M / 61$ & Mac. Ad. & - & Al \\
\hline Til20 & $F / 64$ & Mac. Ad. & - & Al \\
\hline Til2 & $F / 4 I$ & Mix. Ad. & - & Al \\
\hline Ti23 & $F / 58$ & Mix. Ad. & - & Al \\
\hline Ti39 & $F / 46$ & Mix. Ad. & - & Al \\
\hline Ti60 & $F / 42$ & Mix. Ad. & - & Al \\
\hline Till9 & $M / 69$ & Mix. Ad. & - & Al \\
\hline Ti28 & $F / 12$ & Micr. Ad. & - & $\mathrm{Al} / \mathrm{A} 2$ \\
\hline Ti29 & $F / 28$ & Micr. Ad. & - & $\mathrm{Al} / \mathrm{A} 2$ \\
\hline Ti32 & $\mathrm{F} / 43$ & Micr. Ad. & - & Al \\
\hline Ti4I & $F / 43$ & Micr. Ad. & - & Al \\
\hline Til5 & $M / 57$ & WIFC & - & Al \\
\hline Til6 & $F / 26$ & WIFC & - & Al \\
\hline
\end{tabular}

aMacr. Ad.=macrofollicular adenoma; Mix. Ad.=mixed adenoma (macro and microfollicular regions); Micr Ad.=microfollicular adenoma; PTC=papillary thyroid carcinoma; WIFC=widely invasive follicular carcinoma. ${ }^{\text {b }}$ Ti40 was positive for RETIPTCI (Bounacer et al, 1997). ' Al: wildtype allele; A2: mutated allele.

$5^{\prime}$-gcatacgcagcctgtaccc- $3^{\prime}$ and (anti-sense) $5^{\prime}$-aagcttgaaggcatcccggccgcc- $3^{\prime}$.

Direct sequence analysis of the amplified DNA fragments was carried out by the dideoxy-nucleotide method with $\left[\gamma^{33} \mathrm{P}\right]$ ATP, using the double strand DNA cycle sequencing system kit (BRL, Life Technologies) and the same primers as those employed for the amplification, following the manufacturer's conditions. The reaction mixtures were then resolved on standard $8 \%$ acrylamide sequencing gels. Following electrophoresis, gels were dried and autoradiographed with X-ray film overnight.

To look for the presence of an eventual polymorphism in codon 691 RET (see below) by restriction enzyme digestion, $20 \mu \mathrm{l}$ of purified exon 11 amplification product, was digested with $20 \mathrm{U}$ of BanI (Biolabs) at $37^{\circ} \mathrm{C}$ all overnight for a complete digestion. After incubation the samples were separated by electrophoresis in a $2 \%$ agarose gel (see Figure 3). Indeed, when a GGT $\rightarrow$ AGT sequence variant at codon 691 is present, there is loss of a BanI restriction site and only one fragment of $408 \mathrm{bp}$ (mutated allele A2) is detected instead of normally two fragments of 185 and $223 \mathrm{bp}$ (wild type allele A1).

Statistical analysis was made using the Chi-square test to determine whether the associations between radiation-induced thyroid tumours with follicular phenotypes and $\mathrm{CCH}$; and between G691S RET sequence variant and $\mathrm{CCH}$, were significant.

\section{RESULTS}

The population of patients receiving therapeutic radiation in infancy consisted of 29 subjects (18 women, 11 men; sex ratio F/ $\mathrm{M}: 1.63)$, ranging in age at diagnosis from 5 to 58 years, with a mean age of 29.8 years. Only two patients were over 50 years of age (Table 1). The immunohistochemical study showed that 16 patients (55\%), 10 women and $6 \mathrm{men}$, had C-cell hyperplasia $(\mathrm{CCH})$ in the non-neoplastic peritumoural thyroid tissue. The tumours of these 16 irradiated patients were classified as follicular adenoma (Ad) in nine of $14(64 \%)$, papillary carcinoma (PTC) in five of $11(45 \%)$, and widely invasive follicular carcinoma (WIFC) in two of $4(50 \%)$ (Table 1). As control, a total of 29 sporadic thyroid tumours obtained from patients without any history of radiation (sex ratio F/M: 2.6; average age at diagnosis: 40.4 years) and 20 unrelated normal thyroid tissues were screened for $\mathrm{CCH}$. The C-cell hyperplasia was present in just $7 \%(2 / 29)$ of the thyroid glands presenting a sporadic tumour (1/15 Ad: 6.7\%, 1/12 PTC: $8.4 \%$, and $0 / 2$ WIFC) (Table 2$)$, and $10 \%(2 / 20)$ of the unrelated normal thyroid tissues (data not shown).

The C-cell hyperplasia was observed in normal tissue surrounding tumours from all patients who had received external radiation before the age of 15 , with an average of 4.6 years (16/16; Table 1). There was no relationship between the dose of radiation to the thyroid and the presence of $\mathrm{CCH}$ (Table 1). One example of $\mathrm{CCH}$, as defined in Materials and Methods, in peritumoural tissue of a patient with a radiation-induced thyroid tumour is shown in Figure 1. As expected, all thyroid tumours, adenomas, follicular carcinomas, and papillary carcinomas were calcitonin negative.

We looked then for the eventual presence of RET genetic alterations in our radiation-associated and sporadic tumours as well as in samples of unrelated normal thyroid tissue. We began our study investigating the presence or absence of point mutations in exons 10 and 11 of the gene. After PCR the amplified DNAs were directly sequenced. No mutations were detected in exon 10. However, a 
sequence variant in codon 691 of exon 11, changing a $G$ to an $A$ (GGT $\rightarrow$ AGT: gly $\rightarrow$ ser) and giving rise to a single nucleotide polymorphism (SNP) already described in the literature (Bugalho et al, 1994, Ceccherini et al, 1994; Gardner et al, 1994), was observed in

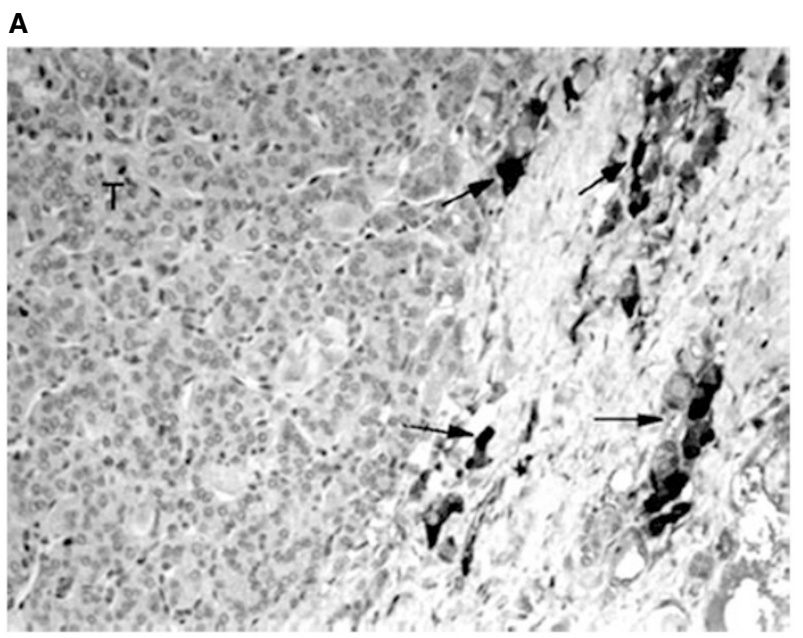

B

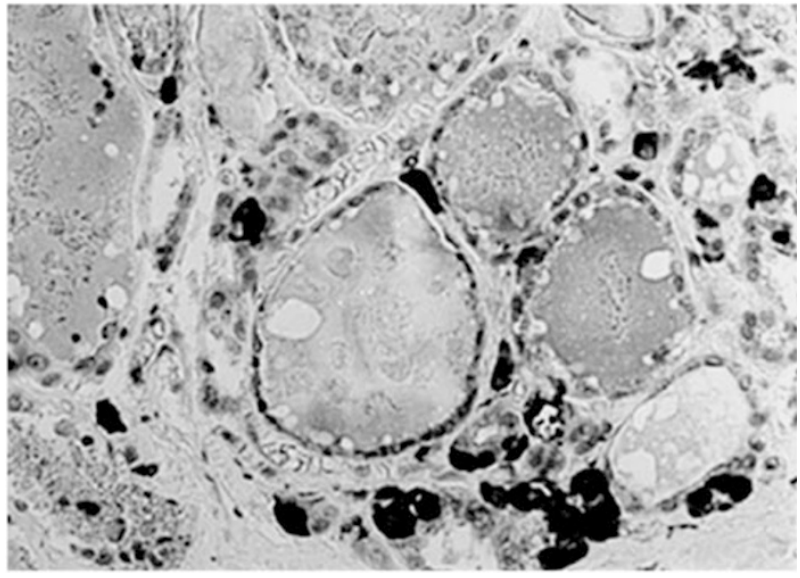

Figure I (A) Presence of C-cell hyperplasia in the peritumoural tissue of a radiation-induced thyroid tumour (T) of patient Ti226 ( $\times 100$ magnification). The arrows indicate calcitonin positive C-cells. (B) The same C-cell hyperplasia seen with $\times 250$ magnification. The calcitonin C-cells was detected by immunohistochemistry using a polyclonal anti-calcitonin antibody.
$55 \%$ of the thyroid radiation-associated tumours (16/29). The frequency of this SNP, which eliminates a BanI restriction site, was similar in radiation-associated follicular adenomas and carcinomas (8/14 Ad: 57\%, 6/11 PTC: 54.5\%, and 2/4 WIFC: 50\%; Table 3). Among the adenomas, a higher frequency of SNP was observed in microfollicular tumours (6/7: 86\%), whereas the frequency was similar in the follicular or papillary carcinomas (Table 3). This 691 RET sequence variant was also detected in $20 \%$ of sporadic tumours $(6 / 29)$ and $15 \%$ of the control normal thyroid tissues (3/20) (Table 3). Again the highest frequency of SNP among the sporadic tumours was observed in the microfollicular adenomas (2/4: $50 \%)$.

With the aim of determining a relationship between C-cell hyperplasia and the G691S RET SNP, we looked in the same thyroid sample for the polymorphism in the tumoural tissue and for the $\mathrm{CCH}$ in the surrounding peritumoural tissue. Our results showed that firstly, the majority of the radiation-induced tumours associated with a $\mathrm{CCH}(14 / 16: 88 \%)$, presented the polymorphism and interestingly, in $75 \%$ of the cases $(12 / 16)$ only the mutated allele A2 was detected. Secondly, in the absence of $\mathrm{CCH}$ in peritumoural tissue only $14 \%(2 / 13)$ of the radiation-induced tumours presented a 691 RET sequence variant in heterozygote form (A1/ A2) (Table 1 and Figure 2).

In the sporadic thyroid tumours, the C-cell hyperplasia was observed in peritumoural tissue of only two of the 29 samples (7\%) which one of them presented only a mutated allele A2 (Table 2 and Figure 2). No G691S RET sequence variant was detected in the DNA prepared from two of 20 samples of unrelated normal thyroid tissues presenting a $\mathrm{CCH}$. Three of the 18 samples remaining were scored for the G691S RET SNP at heterozygote form (A1/ A2) (data not shown).

The blood samples were collected from 12 of our patients with radiation-induced thyroid tumours, and the DNAs extracted from the lymphocytes were screened for the G691S RET sequence variant. Among them, seven samples were from patients with tumours associated with a C-cell hyperplasia in peritumoural tissue (Ti 226, 230, 233, 234, 239, 247 and 249 in Table 1). Six of them were heterozygous (A1/A2) for the G691S SNP and interestingly, in all of the cases the wild type allele A1 was lost in the tumours (loss of heterozygosity?). The only exception was the case $\mathrm{Ti} 233$ in which the tumour as well as the lymphocytes showed only the mutated allele A2. The DNA of lymphocytes of the other five patients whose radiation-induced tumours were not associated with a $\mathrm{CCH}$ presented as in the tumours, only a 691 codon wild type sequence (Ti 101, 155, 225, 236 and 238 in Table 1). All the radiation-associated tumours presenting a G691S RET SNP, with the exception of samples Ti 233 and 255, were positive for a RET/ PTC1 or RET/PTC3 rearrangement. This was also the case for the sporadic tumoural sample Ti 40 (Bounacer et al, 1997; Tables 1 and 2).

Table 3 Frequency of G69IS RET single nucleotide polymorphism in radiation-induced and sporadic thyroid tumours

\begin{tabular}{lccc}
\hline & $\begin{array}{c}\text { Radiation-induced thyroid tumours } \\
\mathbf{1 6 / 2 9}^{\mathrm{b}}: \mathbf{5 5 \%}\end{array}$ & $\begin{array}{c}\text { Sporadic thyroid tumours } \\
\mathbf{6 / 2 9}: \mathbf{2 0} \%\end{array}$ & $\begin{array}{c}\text { Normal thyroid tissue } \\
\mathbf{3 / 2 0}: \mathbf{1 5 \%}\end{array}$ \\
\hline Adenomas & & & \\
Mac. Ad. & & & - \\
Mix. Ad. & $1 / 4: 25 \%$ & $1 / 6: 17 \%$ & - \\
Mic. Ad. & $1 / 3: 33 \%$ & $0 / 5: 0 \%$ & - \\
& $6 / 7: 86 \%$ & $2 / 4: 50 \%$ & - \\
WIFC & $8 / 14: 57 \%$ & $3 / 15: 20 \%$ & - \\
PTC & $2 / 4: 50 \%$ & $0 / 2: 0 \%$ & - \\
\hline
\end{tabular}

aMacr. Ad.=macrofollicular adenoma; Mix. Ad.=mixed adenoma (macro and microfollicular regions); Micr. Ad.=microfollicular adenoma; PTC=papillary thyroid carcinoma; WIFC=widely invasive follicular carcinoma. ${ }^{\text {b }}$ Number of positives/number of tumours studied. 
Key:

C-cell hyperplasia present in peritumoural tissue.

C-cell hyperplasia absent in peritumoural tissue.

A

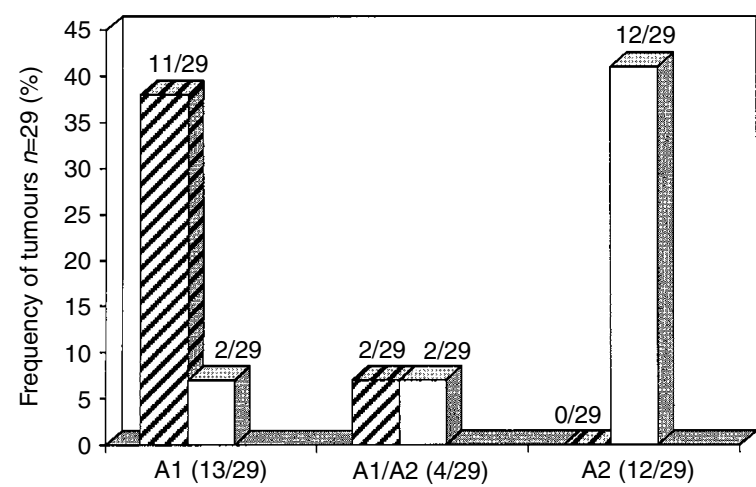

B

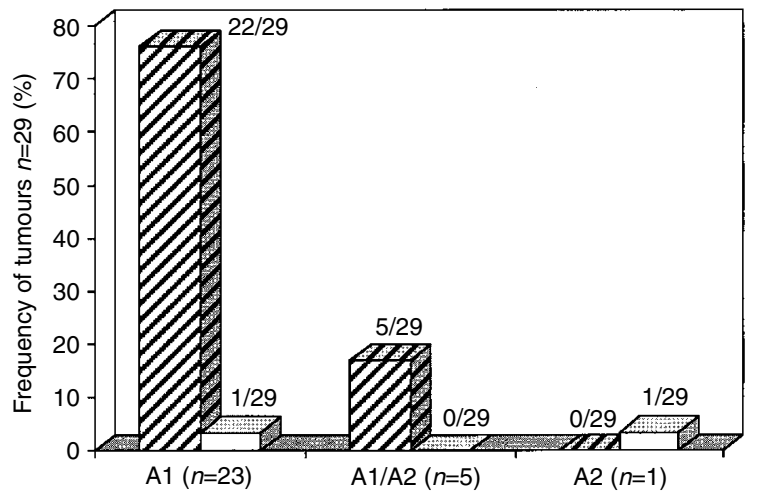

Figure 2 Frequency of radiation-induced $(\mathbf{A})$ and sporadic $(\mathbf{B})$ thyroid tumours $(n=29)$ presenting a wild type allele $A \mathrm{I}$, or mutated allele $\mathrm{A} 2$, or both $(\mathrm{A} 1+\mathrm{A} 2)$ in the presence or absence of C-cell hyperplasia in peritumoural tissue. C-cell hyperplasia was associated with 55\% (I6/29) of the tumours in (A) and with only $7 \%(2 / 29)$ of the tumours in (B).

Examples of the RET G691S RET sequence variant studied by sequence or restriction enzyme digestion, are given in Figure 3.

\section{DISCUSSION}

Our results show a significantly higher frequency of C-cell hyperplasia in peritumoural thyroid tissues of radiation-induced epithelial thyroid tumours (55\%), than in peritumoural tissues of sporadic thyroid tumours $(7 \%)$ or in control normal thyroid tissues $(10 \%) \quad(P=0.0001$, Chi-square test $)$. The presence of $\mathrm{CCH}$ in the non-neoplastic tissue adjacent to follicular cell tumours was previously reported with a frequency of 35\% by Albores-Saavedra et al (1988). However, the authors defined $\mathrm{CCH}$ when at least $50 \mathrm{C}$-cells were observed in only one lower power field $(\times 100$ magnification $)$ rather than at least three fields according to our criteria, and probably some of their positive cases will be taken by us as a negative.

Several conditions such as hyperparathyroidism, hypercalcemia, infancy and chronic lymphatic thyroiditis (Wolfe et al, 1975a,b; Gibson et al, 1980; DeLellis, 1992; Tomita and Millard, 1992), are now admittedly associated with $\mathrm{CCH}$, whereas others, such as age and sex, are still subject to controversy (Gibson et al, 1982; O'Toole et al, 1985; Albores-Saavedra et al, 1988; Scopsi et al, 1991; Guyetant et al, 1997; Harach, 1997). In our patients with a history of external radiation, no correlation has been seen in the sex ratio between the $\mathrm{CCH}$ positive and $\mathrm{CCH}$ negative groups (1.66 and 1.6 respectively). Moreover, we did not observe any significant difference (using Mann-Witney analysis) according to age at diagnosis between these two groups (mean age: 26.6 years in $\mathrm{CCH}$ positive group (excluding the youngest patients Ti85 and Ti233) and 37 years in $\mathrm{CCH}$ negative group). However, all of the patients showing the $\mathrm{CCH}$ in normal tissue surrounding tumours had received external radiation in infancy before the age of 15 (with an average of 4.6 years) and their tumours occurred with an average of 20 years. According to the fact that up to date there is no data reporting that medullary thyroid carcinomas, in which $\mathrm{CCH}$ is considered as a pre-neoplastic stage, are associated with radiation, we can postulate an indirect role of irradiation in the occurrence of $\mathrm{CCH}$. In fact, we have shown the presence of a sequence variant (GGT $\rightarrow$ AGT: gly $\rightarrow$ ser), in codon 691 of exon 11 of the RET gene, giving rise to a polymorphism, in $55 \%$ of radiation-associated thyroid tumours. This polymorphism was present in the majority $(88 \%)$ of these radiation-induced tumours associated with a $\mathrm{CCH}$ in peritumoural tissues. Interestingly, in $75 \%$ of these samples only the mutated allele A2 was detected. In the absence of $\mathrm{CCH}$, the polymorphism was observed in a minority of the radiation-induced tumours in a heterozygous form (A1/A2).

In sporadic epithelial thyroid tumours and in normal thyroid tissues, the frequency of this polymorphism was similar (15 to $20 \%)$ and significantly lower than in radiation-associated tumours ( $P=0.0032$, Chi-square test). Moreover, the C-cell hyperplasia was observed in peritumoural tissue of only two of the 29 sporadic thyroid tumours studied and just one of them presented a serine residue (allele A2) on the codon 691 of the RET protein. In all the other normal or tumoural sporadic thyroid tissues studied for which the $\mathrm{CCH}$ was not observed, the sequence of the codon 691 RET was in wild type (majority of cases) or in heterozygote form (A1/A2).

Our data indicate a correlation between the presence of a C-cell hyperplasia in peritumoural irradiated thyroid tissue and the presence of the mutated sequence in codon 691 of the RET protein (allele A2) in neighbouring epithelial thyroid tumours. The molecular bases of this relationship are actually unknown. The possibility of the existence of some functional interconnections between follicular and parafollicular C-cells, has been recently evoked. For instance, Matias-Guiu (1999) and Volante et al (1999) suggested that the microenvironment provided by MTC cells may have the capacity to stimulate the proliferation of follicular cells, giving rise to hyperplastic and/or adenomatous follicles which, sometimes, may evolve in these conditions to a fully neoplastic phenotype. The opposite situation has also been described: the presence of $\mathrm{CCH}$ in thyroid glands with Hashimoto's thyroiditis or adjacent to benign or malignant epithelial tumours (Albores-Saavedra et al, 1988; Libbey et al, 1989; and our present data). Furthermore, it has been also recently observed by Cosci et al (2000) that the allele variants of RET G691S in exon 11 are significantly more frequent in patients with sporadic MTC than in the general population. Moreover, it has been reported that a neutral germline sequence variance S836S RET may somehow predispose to sporadic MTC, especially those that harbour somatic M918T mutation (Gimm et al, 1999). A highly significant association of RET polymorphisms, specifically the variant A45A, with Hirschsprung disease has also been observed (Borrego et al, 1999, 
A

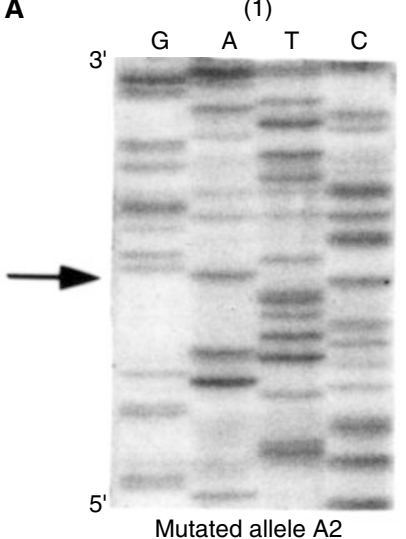

(2)

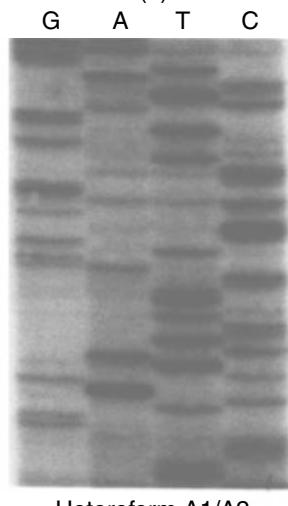

Heteroform A1/A2
(3)

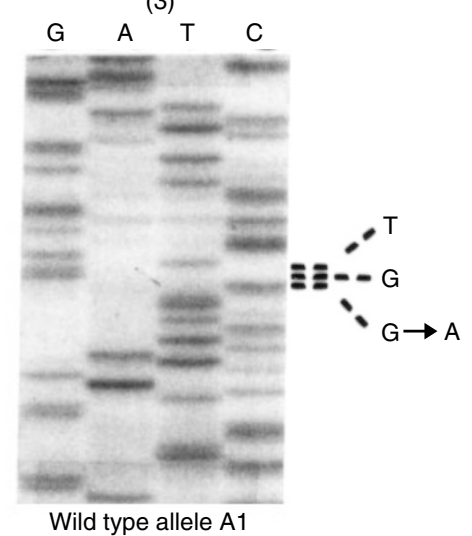

B

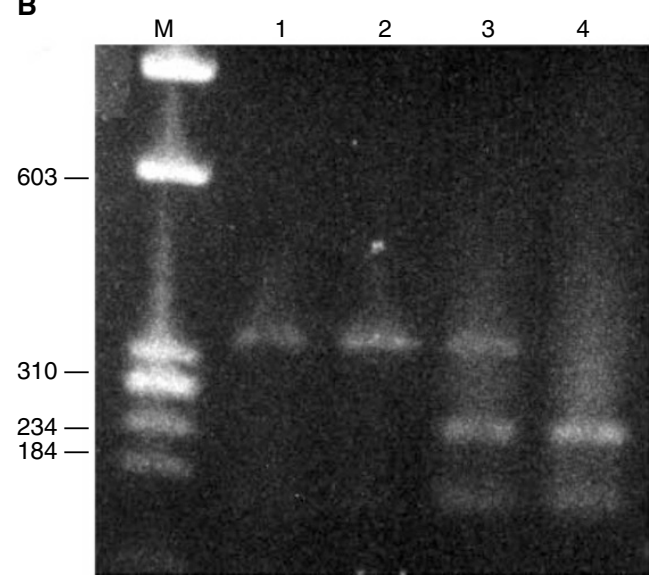

Figure 3 Example of G69I SNP in patient Ti226. (A) Direct sequence of exon I I amplified DNA: (I) radiation-induced thyroid tumour showing mutated allele A2; (2) lymphocytic DNA showing heterozygote form (AI+A2); (3) normal thyroid sample showing wild type allele AI. (B) Banl restriction enzyme digestion of exon 1 I amplified DNA: (I) non-digested; (2) radiation associated tumour (one band: allele A2); (3) lymphocytic DNA (three bands: alleles A I+A2) and (4) normal thyroid sample (two bands: allele AI). In A and $\mathbf{B}$ the material studied after PCR is the same. In B M: marker $\varnothing \times I 74 /$ HaellI digested DNA; 2\% agarose gell stained with ethidium bromide. In $\mathbf{A}$ the arrow indicates the location of the transition $G$ to $A$.

2000; Fitze et al, 1999). Taking into account these and our present data, we suggest that the higher frequency of $\mathrm{CCH}$ observed in the irradiated thyroid glands of the patients bearing in their tumours a G691S RET SNP, may be an effect of the RET allele (or haplotype) on which the sequence variant has occurred.

The precise mechanism by which G691S affect the function of RET protein is unknown and open to speculation. It has been shown that polymorphic sequence variants can lead to production of different amounts of mRNA (Leviev et al, 1997). It may be suggested that the GGT $\rightarrow$ AGT polymorphism causes the creation of a cryptic splice donor, splice acceptor or splice enhancer, therefore leading to an altered protein that may contribute to the development of C-cell hyperplasia. Similar mechanisms have been previously hypothesised in the cases of polymorphisms associated with sporadic MTC and Hirschsprung disease (Borrego et al, 1999; Fitze et al, 1999; Gimm et al, 1999). Unfortunately, RNA from our radio-induced thyroid tumours was not available to test this hypothesis. It can be also postulated when an amino acid is altered for example G691S, depending on the genotype, could subtly alter the function of the RET protein if located in a critical domain. If as a consequence of the radiation received by the thyroid, a pre-existing heterozygous G691S SNP becomes homozygous, the RET protein may be sufficiently affected to overcome a thresh- old of activation and, alone or interacting with other molecules, induce by still unknown mechanisms an accelerated growth of Ccells (see below). This may explain the fact that the growth of C-cells was not affected in $15 \%$ of our normal thyroid tissues and $20 \%$ of the sporadic tumours, by the presence of an A1/A2 heterozygous form. This hypothesis may be supported by data obtained studying the DNA of lymphocytes of some of our patients who presented simultaneously, in their peritumoural thyroid tissues a $\mathrm{CCH}$, and in their radiation-associated tumours only the mutated allele A2. Indeed, the majority of these lymphocytic DNAs (6/7 samples) showed a heterozygous G691S RET variant sequence (A1/A2), suggesting a probable loss of the wild type allele A1 in the tumour samples. Unfortunately, lymphocytic material was not available for all the studied cases; we can speculate a probable similar situation for the cases in which the radiation-associated tumours presented only the mutated allele A2 in association with a $\mathrm{CCH}$ in peritumoural tissues.

Interestingly, all our radiation-induced thyroid tumours (except Ti233 and Ti255) presenting the mutated allele A2 and showing a $\mathrm{CCH}$ in peritumoural tissues are positive for RET/PTC rearrangements (Table 1 and Bounacer et al, 1997). This association between RET/PTC and the allele A2 may contribute to a $\mathrm{CCH}$ observed in peritumoural tissues of these tumours. The hypothesis 
that an eventual stimulation of RET expression in tumoural follicular cells may give rise to the development of a $\mathrm{CCH}$ in their environment, can be supported by recent data from Bunone et al (2000). Indeed these authors showed that there is RET expression in thyroid benign or malignant tumoural follicular cells and in these cells the RET promoter is always active after RET/PTC rearrangement. They reported also that a functional proto-RET receptor might be expressed in epithelial thyroid carcinomas in the absence of RET/PTC. Finally, the authors concluded that the stimulation of RET expression may contribute to a simultaneous or alternative higher proliferation of both follicular and neighbouring parafollicular cells. In this context, we cannot exclude that the mutated G691S RET allele, over-represented in the epithelial radiation-associated tumours compared to controls, may lie in linkage disequilibrium with other sequences that may confer low level predisposition to or protection against anarchic growth of C-cells. Furthermore, the possibilities of an interaction of the modified RET protein with other molecules to stimulate C-cell growth must not be neglected.

Theoretically, polymorphisms represent sequence variations, which are present in the general population and confer no obvious or important deleterious effects. However, it becomes clear that

\section{REFERENCES}

Airaksinen MS, Titievsky A, Saarma M (1999) GDNF family neurotrophic factor signaling: four masters, one servant? Mol Cell Neurosci 13: 313-325 Albores-Saavedra J, Monforte H, Nadji M, Morales AR (1988) C-cell hyperplasia in thyroid tissue adjacent to follicular cell tumors. Hum Pathol 19: 795-799

Baloh RH, Enomoto H, Johnson Jr EM, Milbrandt J (2000) The GDNF family ligands and receptors - implications for neural development. Curr Opin Neurobiol 10: $103-110$

Borrego S, Ruiz A, Saez ME, Gimm O, Gao X, Lopez-Alonso M, Hernandez A, Wright FA, Antinolo G, Eng C (2000) RET genotypes comprising specific haplotypes of polymorphic variants predispose to isolated Hirschsprung disease. J Med Genet 37: 572-578

Borrego S, Saez ME, Ruiz A, Gimm O, Lopez-Alonso M, Antinolo G, Eng C (1999) Specific polymorphisms in the RET proto-oncogene are over-represented in patients with Hirschsprung disease and may represent loci modifying phenotypic expression. J Med Genet 36: 771-774

Bounacer A, Wicker R, Caillou B, Cailleux AF, Sarasin A, Schlumberger M, Suarez HG (1997) High prevalence of activating ret proto-oncogene rearrangements, in thyroid tumors from patients who had received external radiation. Oncogene 15: $1263-1273$

Bugalho MJ, Cote GJ, Khorana S, Schultz PN, Gagel RF (1994) Identification of a polymorphism in exon 11 of the RET protooncogene. Hum Mol Genet 3: 2263

Bunone G, Uggeri M, Mondellini P, Pierotti MA, Bongarzone I (2000) RET receptor expression in thyroid follicular epithelial cell-derived tumors. Cancer Res 60: 2845-2849

Ceccherini I, Hofstra RM, Luo Y, Stulp RP, Barone V, Stelwagen T, Bocciardi R, Nijveen H, Bolino A, Seri M, Ronchetto P, Pasini B, Bozzano M, Buys C, Romeo G (1994) DNA polymorphisms and conditions for SSCP analysis of the 20 exons of the ret proto-oncogene. Oncogene 9: 3025-3029

Conard R (1984) Late radiation effects in Marshall islanders exposed to fallout 28 years ago. In Radiation carcinogenesis: epidemiology and biology significance, Boice JD, Fraumeni JF (eds) pp 57-70. New York: Raven Press

Cosci B, Romei C, Vivaldi A, Bottici V, Rosselli R, Bonotti A, Lari R, Pinchera A (2000) RET exon 11 (G691) polymorphism is significantly more frequent in medullary thyroid carcinoma than in the general population (Abstract). J Endocrinol Invest 23: 5

DeLellis RA, Wolfe HJ (1981) The pathobiology of the human calcitonin (C)cell: a review. Pathol Annu 16: 25-52

DeLellis RA (1992) C-cell hyperplasia. In Atlas of tumor pathology, 3rd series, fasc 5: Tumors of the thyroid gland, Rosai J, Carcangiu ML, DeLellis RA (eds) pp 247-258. Washington, DC: Armed Forces Institute of Pathology some polymorphisms like the APC gene in colorectal cancer in the Ashkenazim (Laken et al, 1997) and the paraoxonase gene in coronary heart disease in type 2 diabetes (Ruiz et al, 1995) are not entirely harmless. These observations taken together with our present data argue in favour that RET G691S variant can constitute a factor contributing to the development of $\mathrm{CCH}$ in the peritumoural tissues of irradiated thyroid glands. Further efforts must be aimed to confirm a loss of the 691 RET wild type allele in the irradiated thyroid tumours associated with a $\mathrm{CCH}$; and also to clarify by which mechanisms the microenvironment provided by these tumours positive for G691S mutated allele has the capacity to stimulate the development of $\mathrm{CCH}$.

\section{ACKNOWLEDGEMENTS}

We would like to thank Michèle Chaker for secretarial assistance. We thank the Ligue Nationale Française contre le Cancer, Ministère de l'Education et de la Recherche, Centre National de la Recherche Scientifique and Association de la Recherche sur le Cancer (France) for grant support (to HG Suarez).

Diallo I, Lamon A, Shamsaldin A, Grimaud E, de Vathaire F, Chavaudra J (1996) Estimation of the radiation dose delivered to any point outside the target volume per patient treated with external beam radiotherapy. Radiother Oncol 38: 269-271

Donis-Keller H, Dou S, Chi D, Carlson KM, Toshima K, Lairmore TC, Howe JR, Moley JF, Goodfellow P, Wells Jr SA. (1993) Mutations in the RET proto-oncogene are associated with MEN 2A and FMTC. Hum Mol Genet 2: $851-856$

Duffy BJJ, Fitzgerald PJ (1950) Cancer of the thyroid in children: A report of 28 cases. J Clin Endocrinol Metab 10: $1296-1308$

Edery P, Lyonnet S, Mulligan LM, Pelet A, Dow E, Abel L, Holder S, NihoulFekete C, Ponder BA, Munnich A (1994) Mutations of the RET protooncogene in Hirschsprung's disease. Nature 367: 378-380

Eng C (1999) RET proto-oncogene in the development of human cancer. $J$ Clin Oncol 17: 380-393

Fabien N, Paulin C, Santoro M, Berger N, Grieco M, Dubois PM, Fusco A (1994) The RET proto-oncogene is expressed in normal human parafollicular thyroid cells. Int J Oncol 4: 623-626

Fitze G, Schreiber M, Kuhlisch E, Schackert HK, Roesner D (1999) Association of RET protooncogene codon 45 polymorphism with Hirschsprung disease. Am J Hum Genet 65: 1469-1473

Gardner E, Mulligan LM, Eng C, Healey CS, Kwok JB, Ponder MA, Ponder BA (1994) Haplotype analysis of MEN 2 mutations. Hum Mol Genet 3: $1771-1774$

Gibson W, Croker B, Cox C (1980) C-cell populations in normal children and young adults. Lab Invest 42: 119-120

Gibson WG, Peng TC, Croker BP (1982) Age-associated C-cell hyperplasia in the human thyroid. Am J Pathol 106: 388-393

Gimm O, Neuberg DS, Marsh DJ, Dahia PL, Hoang-Vu C, Raue F, Hinze R, Dralle H, Eng C (1999) Over-representation of a germline RET sequence variant in patients with sporadic medullary thyroid carcinoma and somatic RET codon 918 mutation. Oncogene 18: 1369-1373

Guyetant S, Dupre F, Bigorgne JC, Franc B, Dutrieux-Berger N, LecomteHoucke M, Patey M, Caillou B, Viennet G, Guerin O, Saint-Andre JP (1999) Medullary thyroid microcarcinoma: a clinicopathologic retrospective study of 38 patients with no prior familial disease. Hum Pathol 30: $957-963$

Guyetant S, Rousselet MC, Durigon M, Chappard D, Franc B, Guerin O, Saint-Andre JP (1997) Sex-related C cell hyperplasia in the normal human thyroid: a quantitative autopsy study. J Clin Endocrinol Metab 82: 42-47 
Guyetant S, Wion-Barbot N, Rousselet MC, Franc B, Bigorgne JC, SaintAndre JP (1994) C-cell hyperplasia associated with chronic lymphocytic thyroiditis: a retrospective quantitative study of 112 cases. Hum Pathol 25: $514-521$

Harach HR (1997) Age, sex and C cells: what about the human thyroid follicle with acid mucin and solid cell nests? J Clin Endocrinol Metab 82: 4274

Hedinger C, Williams ED, Sobin LH (1988) Histological typing of thyroid tumours. In 2nd ed. No 11 of International histological classification of tumours, Hedinger C, Williams ED and Sobin LH (eds). Berlin, Germany: Springer-Verlag

Hofstra RM, Landsvater RM, Ceccherini I, Stulp RP, Stelwagen T, Luo Y, Pasini B, Hoppener JW, van Amstel HK, Romeo G, Lips C, Buys C (1994) A mutation in the RET proto-oncogene associated with multiple endocrine neoplasia type $2 \mathrm{~B}$ and sporadic medullary thyroid carcinoma. Nature 367: $375-376$

Kazakov VS, Demidchik EP, Astakhova LN (1992) Thyroid cancer after Chernobyl. Nature 359: 21

Laken SJ, Petersen GM, Gruber SB, Oddoux C, Ostrer H, Giardiello FM, Hamilton SR, Hampel H, Markowitz A, Klimstra D, Jhanwar S, Winawer S, Offit K, Luce MC, Kinzler KW, Vogelstein B (1997) Familial colorectal cancer in Ashkenazim due to a hypermutable tract in APC. Nat Genet 17: $79-83$

Leviev I, Negro F, James RW (1997) Two alleles of the human paraoxonase gene produce different amounts of mRNA. An explanation for differences in serum concentrations of paraoxonase associated with the (Leu-Met54) polymorphism. Arterioscler Thromb Vasc Biol 17: 2935-2939

Libbey NP, Nowakowski KJ, Tucci JR (1989) C-cell hyperplasia of the thyroid in a patient with goitrous hypothyroidism and Hashimoto's thyroiditis. Am J Surg Pathol 13: $71-77$

LiVolsi VA (1997) C cell hyperplasia/neoplasia. J Clin Endocrinol Metab 82: $39-41$

Matias-Guiu X (1999) Mixed medullary and follicular carcinoma of the thyroid. On the search for its histogenesis. Am J Pathol 155: 1413-1418

Mulligan LM, Kwok JB, Healey CS, Elsdon MJ, Eng C, Gardner E, Love DR, Mole SE, Moore JK, Papi L, Ponder MA, Telenius H, Tunnacliffe A, Ponder BAJ (1993) Germ-line mutations of the RET proto-oncogene in multiple endocrine neoplasia type 2A. Nature 363: 458-460

O’Toole K, Fenoglio-Preiser C, Pushparaj N (1985) Endocrine changes associated with the human aging process: III. Effect of age on the number of calcitonin immunoreactive cells in the thyroid gland. Hum Pathol 16: $991-1000$

Pachnis V, Mankoo B, Costantini F (1993) Expression of the c-ret protooncogene during mouse embryogenesis. Development 119: 1005 - 1017
Ron E, Lubin JH, Shore RE, Mabuchi K, Modan B, Pottern LM, Schneider AB, Tucker MA, Boice Jr JD (1995) Thyroid cancer after exposure to external radiation: a pooled analysis of seven studies. Radiat Res 141: 259-277

Ruiz J, Blanche H, James RW, Garin MC, Vaisse C, Charpentier G, Cohen N, Morabia A, Passa P, Froguel P (1995) Gln-Arg192 polymorphism of paraoxonase and coronary heart disease in type 2 diabetes. Lancet 346: 869872

Scopsi L, Di Palma S, Ferrari C, Holst JJ, Rehfeld JF, Rilke F (1991) C-cell hyperplasia accompanying thyroid diseases other than medullary carcinoma: an immunocytochemical study by means of antibodies to calcitonin and somatostatin. Mod Pathol 4: 297-304

Shore RE (1992) Issues and epidemiological evidence regarding radiationinduced thyroid cancer. Radiat Res 131: 98-111

Suarez HG (1998) Genetic alterations in human epithelial thyroid tumours. Clin Endocrinol (Oxf) 48: $531-546$

Suarez HG, du Villard JA, Caillou B, Schlumberger M, Parmentier C, Monier R (1991) gsp mutations in human thyroid tumours. Oncogene 6: 677-679

Suarez HG, du Villard JA, Severino M, Caillou B, Schlumberger M, Tubiana M, Parmentier C, Monier R (1990) Presence of mutations in all three ras genes in human thyroid tumors. Oncogene 5: 565-570

Takahashi M, Cooper GM (1987) ret transforming gene encodes a fusion protein homologous to tyrosine kinases. Mol Cell Biol 7: 1378-1385

Takahashi M, Ritz J, Cooper GM (1985) Activation of a novel human transforming gene, ret, by DNA rearrangement. Cell 42: $581-588$

Thompson DE, Mabuchi K, Ron E, Soda M, Tokunaga M, Ochikubo S, Sugimoto S, Ikeda T, Terasaki M, Izumi S, Preston DL (1994) Cancer incidence in atomic bomb survivors. Part II: Solid tumors, 1958-1987. Radiat Res 137: $17-67$

Tomita T, Millard DM (1992) C-cell hyperplasia in secondary hyperparathyroidism. Histopathology 21: 469-474

Volante M, Papotti M, Roth J, Saremaslani P, Speel EJ, Lloyd RV, Carney JA, Heitz PU, Bussolati G, Komminoth P (1999) Mixed medullary-follicular thyroid carcinoma. Molecular evidence for a dual origin of tumor components. Am J Pathol 155: 1499-1509

Wolfe HJ, DeLellis RA, Scott RT, Tashjian AH (1975a) C-cell hyperplasia in chronic hypercalcemia in man (abstract). Am J Pathol 78: $20 \mathrm{~A}$

Wolfe HJ, DeLellis RA, Voelkel EF, Tashjian AH (1975b) Distribution of calcitonin-containing cells in the normal neonatal human thyroid gland: a correlation of morphology with peptide content. J Clin Endocrinol Metab 41: $1076-1081$

Wolfe HJ, Melvin KE, Cervi-Skinner SJ, Saadi AA, Juliar JF, Jackson CE, Tashjian AH (1973) C-cell hyperplasia preceding medullary thyroid carcinoma. N Engl J Med 289: 437-441 